\title{
Review of Richard Horton (2020). The Covid-19 \\ Catastrophe: What's Gone Wrong and How to Stop it Happening Again
}

\section{Cambridge, UK and Medford, MA: Polity Press. 133 pp. ISBN 9781509546466 (Paperback)}

\author{
Zoe Hurley $^{1}$ \\ Published online: 27 July 2020 \\ (C) Springer Nature Switzerland AG 2020
}

\section{Double-Shuffle}

Richard Horton, The Lancet's ${ }^{1}$ editor-in-chief, has delivered a swift response to Covid-19. Mid-pandemic, the world is suffering post-traumatic stress disorder as leaders and medical experts appear incoherent and disorganized. Academics also scramble to respond and are producing manifold coronavirus publications. Horton's The Covid-19 Catastrophe: What's Gone Wrong and How to Stop it Happening Again (2020) has managed to stand out for its sharp polemic (Knight 2020). Horton denounces Donald Trump's decision to withdraw funding from the World Health Organization (WHO) as a crime against humanity and accuses Boris Johnson of misconduct in public office. But while being critical of governments for failing their nations, his rebuttal, in my opinion, could have gone further in exposing the rotten nexus of techno-capitalism, the medical industry, and politics at the core of the health crisis. Horton has authority, acumen and social conscience. But his reluctance to strike out more explicitly against the marketisation of national health provision is what sociologist Stuart Hall (2003) might have called a 'double-shuffle.'

At the time of writing this review, the coronavirus has caused over 549,749 deaths and reached 12 million cases globally (BBC News 2020). It has battered economies, public and private sectors. Covid-19 demonstrates the need for health services to care for the many rather than the few. But there are few signs that this pandemic will lead to increased spending on public healthcare, as Trump presses ahead with 'terminating' the Affordable Care Act (Woodward 2020). Britain's National Health Service (NHS) was irreversibly reduced by Thatcherism in the 1980s and undone further by backdoor privatisation throughout the 2000s (Hall 2011). During the current coronavirus crisis,

${ }^{1}$ See https://www.thelancet.com/. Accessed 10 July 2020.

Zoe Hurley

Zoe.hurley@zu.ac.ae

1 Zayed University, Dubai, United Arab Emirates 
key workers, doctors and nurses are applauded as heroes. This is poignant and welldeserved but negates from the behind-the-scenes' trashing of public funding for health services, medical science and academic research. Rather than the Covid-19 emergency strengthening of national health services, we are more likely to end up with the reverse. Simultaneously, the WHO's, doctors' and scientists' ability to speak effectively on the issues continues to be undermined and effectively muzzled. Horton conveys that the current pandemic is also a discursive crisis.

\section{Philosophy of Fear}

Horton points out that Covid-19 is triggering a domino fall of experts' reputations, officials shirking responsibilities, and politicians pivoting. Trump has blamed China and the WHO. Horton blames Trump, the British government and ineffectual leaders, incensed by the nonsense shouted and tweeted by Trump, Johnson, and Jair Bolsonaro in Brazil. But their voters, who are also experiencing intense economic, social and health insecurity, evidently crave solutions, digestible promises and easy to blame targets in this undeniable emergency. Therefore, to understand the extent to which the Covid-19 pandemic is also a political crisis, we need to reflect more critically on why millions of people, suffering economic hardships, health dangers and environmental catastrophe, vote for parties who capitalise on hyper-inequalities and divisive individualism.

Horton understands that human beings can be driven by anxiety, as he quotes Lars Svendsen's A Philosophy of Fear (2008) and returns to him in the final chapter. He also realises that crisis plays an instrumental role in global history. Yet, the discursive emergency is not only top-down. What Horton underestimates, in my view, is the professional classes' acquiescence of the brazen neoliberal cruelty in marketising human life, health and the attack on the state sector. Henry Giroux (2011), amongst other critical pedagogues, has written about the strategic undermining of state education. He suggests neoliberalism, or the logic of marketisation; chips away at investments into the physical buildings, playing fields and precious physical resources; and also erodes the frameworks and vocabularies for thinking and talking about education (Giroux in Jandrić 2017). Insights from Giroux, concerning neoliberalism's cultural apparatus for dismantling material and discursive infrastructure, indicate that the Covid-19 emergency is therefore, in part, the result of the loss of state funding for health services as well as the wearing away of collective thinking about health planning and reactions to pandemics.

Throughout the book's seven chapters, Horton articulates some of these issues around the interconnections of state, health, politics and economics. There are sprinklings of political theory: Benthamite history; Foucauldian philosophy of surveillance culture; Didier Fassin's (2018) public-health anthropology, addressing the racialised and discriminatory biopolitics of life and otherness; and reference to Slavoj Žižek's (2020) musings on the Covid-19 pandemic. Horton's style is accessible as he maps some of the political, social and medical practices that enmesh the world in crisis. He provides a listing of who has done what, has not done anything or has been misrepresented during the pandemic, while hinting at controversies surrounding The Lancet's slow response and lack of fact checking (Wilson 2020). His ambitious spread 
of information is delivered to readers as heated rhetoric. While this position of anger is no doubt justifiable, considering governments' mismanagement of the health crisis, it is also (ironically) indicative of the current Zeitgeist of Trumpian hot retort.

Horton's coverage is fast and furious, ranging from the pandemic's emergence in China's Wuhan province, the slow international response to the warnings, the paradox of science's success and failure, key workers on the frontline, politics of Covid-19, the continuing risk of pandemics and preparing for futures public health emergencies. He defends Dr. Tedros Adhanom Ghebreyesus, the WHO's director-general, since Dr. Tedros (along with China) has been branded by Trump as the pandemic's fall guy. Trump is a leading figure in Horton's book as lengthy Trump quotes fill the pages. While these ill-formed and often downright offensive responses to the pandemic are certainly bizarre, many readers will be already aware of such 'Trumpisms.' Arguably, Trump's scapegoating of China is a shrewd move (from his camp's perspective) in detracting from American domestic policy. It is a nasty cocktail of latent cold-war tensions and Sinophobia, the anti-Chinese feeling in Europe, USA and other white settler societies that peaked in the nineteenth century (Frayling 2014). Furthermore, we know Trump is not speaking to Democrat voters and/or those on the left, and we urgently require deeper theorising of why Trumpian register resonates, the tacit reasoning and ideology of his discursive moves.

\section{Triumph of Ignorance}

But if this is also a crisis of words, arguably then, it is not enough for Horton to rage against Trump. Trump, Johnson and other inadequate leaders are doing a great job of emphasising their own inadequacies. Instead, we need to reflect more deeply and critically on the Trumpian political and discursive brand in order to reveal the latent, compressed and historical significance of the values that it embodies. Trumpism is the triumph of ignorance over not only science but also professionalism, academic research and social collegiality. In its contemporary form, the Trumpian crisis has descended into a circus of tweets, broad generalisations over fact-checking, bullying rather than compassion, empty gesturing and heckling as opposed to dialogue and debate. But to understand the callousness of the political discursive crisis, we should interrogate its discursive appeal, as a form of negative freedom, to the growing number of antivaxxers, libertarians, patriots and the alt-right. Being free from state control could mean, for some, freedom not to wear a mask, impunity from being tested and/or freefall from social responsibility or any social contract altogether. Trumpism fuels these ideologies while, conveniently, freeing state responsibility.

Horton has been in a hurry to address some of these issues and could be commended for writing this short book so quickly during lockdown but, in his haste, some points are repetitive despite the text being only 133 pages long. Although referring to important issues, including how the health pandemic is being experienced differently by varying countries, ethnic minorities, the working class and women, he does not drill deeply into any particular issue as he jumps from history to medicine, science and political theory. As The Lancet's editor-in-chief, an experienced medical practitioner and doctor, Horton is in a key position to consider the perspectives of care providers, doctors and nurses on the frontline. This book also provides an important opportunity 
to give voice to those bearing the brunt of the underfunding and mismanagement of the health crisis.

Horton does include several pages of quotes from different health professionals, whose sense of incredulity, fear and desperation are apparent. From an ethnographic perspective, I wanted to hear more about these frontline workers' stories, opinions and divergent perspectives since their accounts of the crisis, as it unfolds, are essential testimonies. At a macro level, Horton importantly calls for an international inquiry into the global mishandling of the health crisis since a post-pandemic reckoning will be necessary. But the international community's more unified responses to injustice historically, for example the Nuremberg Trials held by the Allies after World War II, or the global support for South Africa's Truth and Reconciliation Commission in 1996, are almost unimaginable on today's fractured world stage. In the midst of the current Covid-19 pandemic and escalating political crisis, it is not clear who will be willing or able to speak for those without a privileged platform. Conversely, Horton (2020: 126) tells us: 'Capitalism has many virtues. But the intense version of capitalism that has emerged over the past forty-years has weakened something essential in the social fabric of our societies. Those weaknesses contributed to the tragic toll of deaths.'

\section{Circling Sharks}

However, considering the scale of the pandemic, governments' global rivalries and policies of competition that Horton signals throughout the book, it is difficult to realise the 'virtues' of capitalism that he refers to in the final chapter. Firstly, capitalism's deep roots go back much further than forty years. Secondly, Horton's phrase 'intense version of capitalism,' insufficiently calls out neoliberalism's contribution to the crisis. Thirdly, the 'something,' that Horton appears reluctant to name are state sector services, operating at the material, ethical and discursive levels. Stuart Hall (2011) addressed neoliberalism's unhealthy bite into the state sector. He explained that the privatisation in the UK, by the early 2000s, was already playing a massive, profit-making role in healthcare through the privatisation of hospitals, care homes and clinics. The conservative government's top-down reorganisation of the NHS, grouped practitioners (GPs) into private consortia, part of whose profits they retained. Since few GPs had the knowhow or time to run complex budgets assigned; they turned to the private health companies who were, according to Hall (2011: 720), 'circling the NHS like sharks waiting to feed.'

Britain's once admirable NHS has been unable to provide enough protective personal equipment or Covid-19 tests for its frontline workers. Horton warns us that the pandemic is far from over, due to the crisis of leadership, and there will likely be other health emergencies from which we may not recover. That is a terrifying prospect and the theme of fear runs throughout Horton's book. Yet, we also need to develop brave responses to Covid-19 and to mitigate against the closing-in of capitalism's circling sharks. As the global health fiasco continues, we should acknowledge that the world leaders are not the only ones running the show and figures like Bill Gates are instrumental in bringing platform capitalism, politics and medicine closer together.

Simultaneously, the problem with neoliberalism's erosion of the state, in the Covid19 moment and beyond, is that private venture capitalists, according to the forward- 
thinking economist Mariana Mazzucato (2018), rarely venture much at all. For example, after the SARS outbreak in 2002-2003, private investors were not willing to invest in coronavirus research while publicly funded research continued, and the US government contributed $\$ 700$ million. Tech giants like Apple, Google and Elon Musk’s companies have also profited from substantial government funding (Bregman 2020). Horton must realise that, while we wait for breakthrough vaccines, they are more likely to come through publicly funded initiatives. Theorising of the Covid-19 crisis could therefore draw strength from an informed axiology, or study of values, to realise the importance of the state, collective and global solutions. An aspect of this involves developing braver critical tools to explore tech-politics, social and medical practices at discursive levels.

\section{References}

BBC News. (2020). Where are the world's coronavirus hotspots? BBC News, 8 July. https://www.bbc. com/news/world-51235105.

Bregman, R. (2020). The neoliberal era is ending. What comes next? The Correspondent, 14 May. https://thecorrespondent.com/466/the-neoliberal-era-is-ending-what-comes-next/61655148676-a00ee89a.

Fassin, D. (2018). Life: a critical user's manual. Cambridge: Polity.

Frayling, C. (2014). The yellow peril: Dr Fu Manchu \& the rise of Chinaphobia. London: Thames and Hudson Ltd.

Giroux, H. (2011). Education and the crisis of public values: challenging the assault on teachers, students and public education. New York: Peter Lang.

Hall, S. (2003). New Labour's double-shuffle. Soundings, 24, 10-24. https://doi.org/10.3898 /136266203820467680.

Hall, S. (2011). The neo-liberal revolution. Cultural Studies, 25(6), 705-728. https://doi.org/10.1080 /09502386.2011.619886.

Horton, R. (2020). The Covid-19 catastrophe: What's gone wrong and how to stop it happening again. Cambridge, UK: Polity Press.

Jandrić, P. (2017). Learning in the age of digital reason. Rotterdam: Sense.

Knight, S. (2020). The Lancet editor's wild ride through the coronavirus pandemic. The New Yorker, 27 June. https://www.newyorker.com/news/letter-from-the-uk/the-lancet-editors-wild-ride-through-thecoronavirus-pandemic.

Mazzucato, M. (2018). The entrepreneurial state. London: Penguin.

Svendsen, L. (2008). A philosophy of fear (2nd ed.). London: Reaktion Books.

Woodward, A. (2020). Trump says administration will continue legal fight to eliminate Obamacare as states brace for Medicaid cuts. The Independent, (8 May) https://www.independent.co. uk/news/world/americas/us-politics/trump-obamacare-end-legal-case-medicaid-cuts-a9504906.html.

Žižek, S. (2020). Pandemic! Covid-19 shakes the world. New York and London: OR Books. 